\title{
ELECTRIC-UTILITY DSM PROGRAMS: 1990 DATA AND FORECASTS TO 2000
}

\author{
ERIC HIRST
}

JUNE 1992

Sponsored by

Office of Conservation and Renewable Energy

U.S. Department of Energy

OAK RIDGE NATIONAL LABORATORY

Oak Ridge, Tennessee 37831 managed by

MARTIN MARIETTA ENERGY SYSTEMS, INC.

under contract No. DE-AC05-84-OR21400

for

U.S. DEPARTMENT OF ENERGY 


\section{TABLE OF CONTENTS}

Page

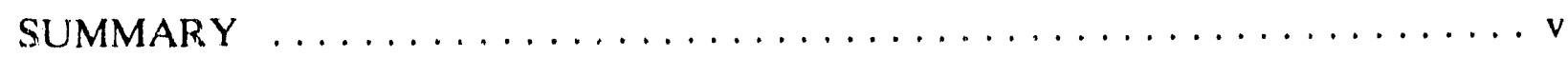

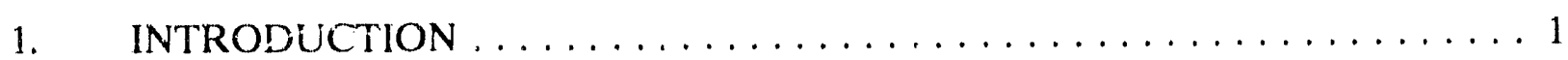

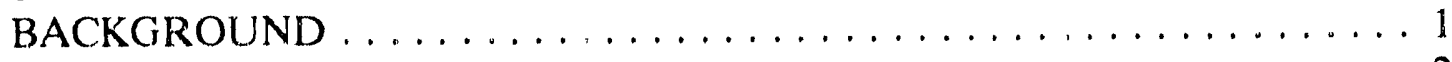

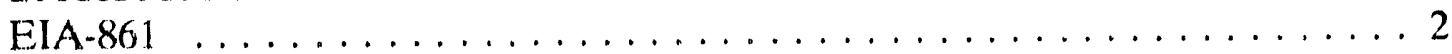

2. DSM-PROGRAM EXPENDITURES $\ldots \ldots \ldots \ldots \ldots \ldots \ldots \ldots \ldots$

3. DSM-PROGRAM ENERGY SAVINGS $\ldots \ldots \ldots \ldots \ldots \ldots \ldots \ldots$

4. DSM-PROGRAM PEAK DEMAND REDUCTIONS $\ldots \ldots \ldots \ldots \ldots$

5. UTILITY FORECASTS, $1991-2000 \ldots \ldots \ldots \ldots \ldots \ldots \ldots \ldots$

6. CAVEATS AND CONCLUSIONS $\ldots \ldots \ldots \ldots \ldots \ldots \ldots$

CAVEATS ............................... 19

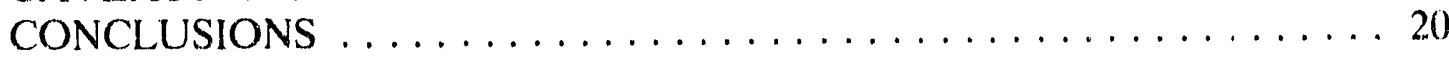

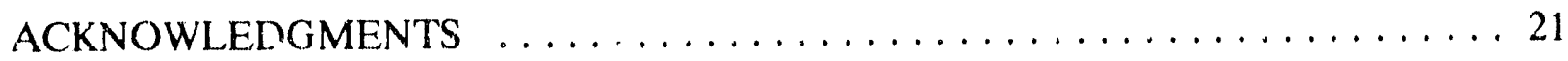

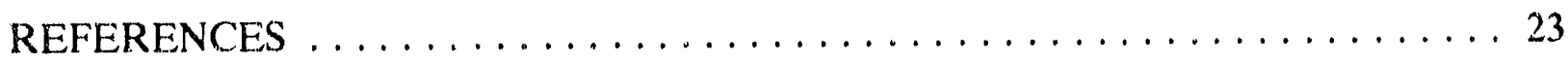




\section{SUMMARY}

In April 1992, the Energ, Information Administration (ElA) released data on 1989 and 1990 electric-utility demand-side management (DSM) programs. These data represent a census of U.S. utility DSM programs, with reports of utility expenditures, energy savings, and load reductions caused by these programs. In addition, EIA published utility estimates of the costs and effects of these programs from 1991 through 2000.

These data provide the first comprehensive picture of what utilities are spending and accomplishing by utility, state, and region. This report presents, summarizes, and interprets the 1990 data and the utility forecasts of their DSM-program expenditures and impacts to the year 2000 . Only utilities with annual sales greater than $120 \mathrm{GWh}$ were required to report data on their DSM programs to EIA. Of the 1,194 such utilities, 363 reported having a DSM program that year.

These 363 electric utilities spent $\$ 1.2$ billion on their DSM programs in 1990, up from $\$ 0.9$ billion in 1989. Estimates of energy savings $(17,100 \mathrm{GWh}$ in 1990 and $14,800 \mathrm{GWh}$ in $1989)$ and potential reductions in peak demand $(24,400 \mathrm{MW}$ in 1990 and about $19,400 \mathrm{MW}$ in 1989) also showed substantial increases. Overall, utility DSM expenditures accounted for $0.7 \%$ of total U.S. electric revenues, while the reductions in energy and demand accounted for $0.6 \%$ and $4.9 \%$ of their respective 1990 national totals (Fig. S-1).

The investor-owned utilities accounted for 70 to $90 \%$ of the totals for DSM costs, energy savings, and demand reductions. The public utilities (which include federal, state, municipal, and cooperative utilities) reported larger percentage reductions in peak demand and energy but smaller percentage DSM expenditures than the investor-owned utilities.

These averages hide tremendous variations across utilities. Almost $30 \%$ of these 363 utilities, for example, reported spending less than $0.1 \%$ of their revenues on DSM programs in $1990 ; 22 \%$ reported spending more than $1 \%$ of their revenues on DSM programs. DSM expenditures exceeded $2 \%$ of utility revenues in Maine, Massachusetts, Rhode Island, and Wisconsin.

Utility forecasts of DSM expenditures and effects show substantial growth in both absolute and relative terms. Real expenditures are forecast to grow at $5 \% / y e a r$, from $\$ 1.2$ billion in 1990 to $\$ 2.0$ billion in 2000 (in 1990 dollars). And DSM expenditures are expected to increase from $0.7 \%$ to $1.5 \%$ of revenues during this decade. 


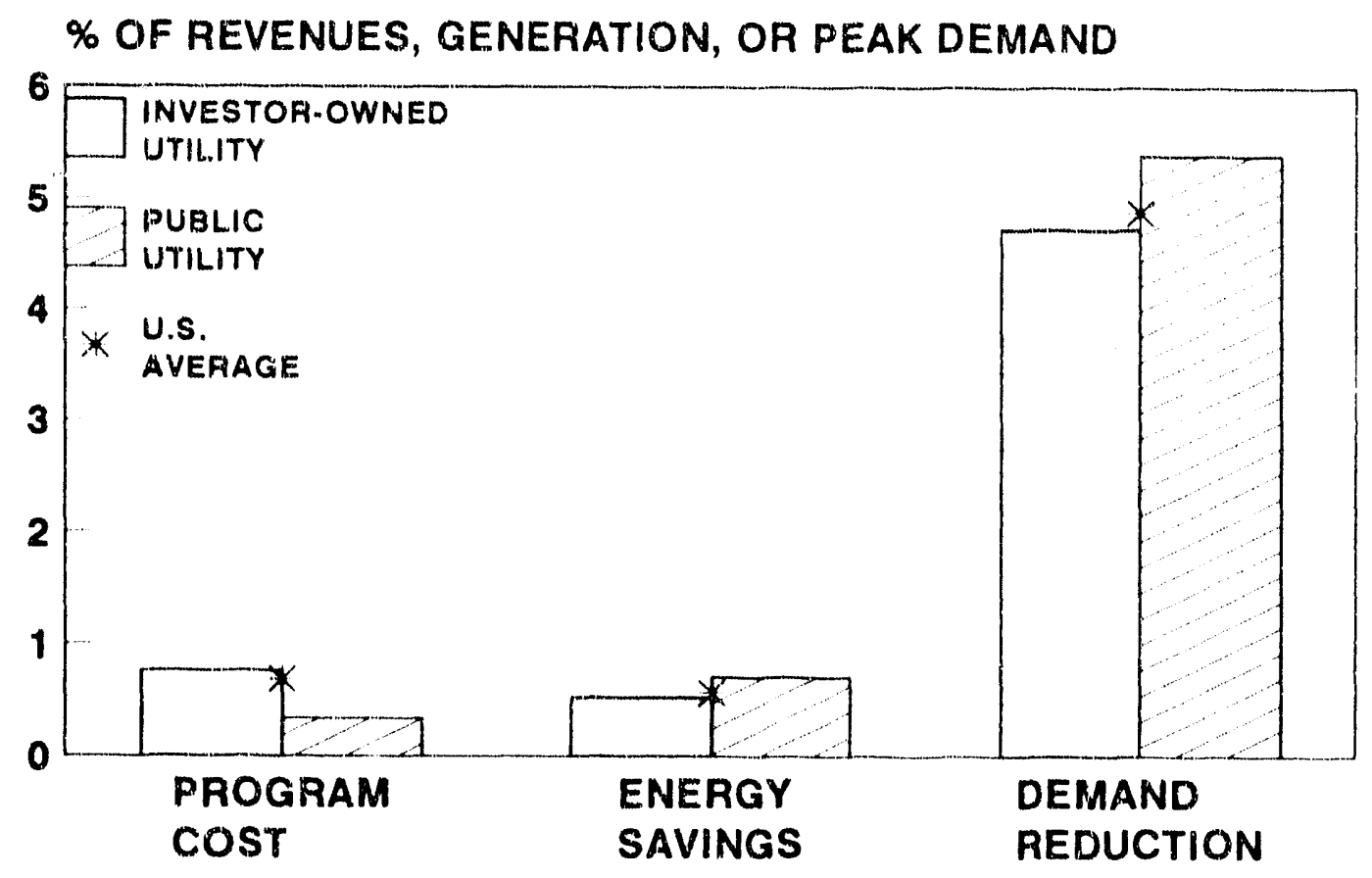

Fig. S-1. The 1990 costs and effects (in terms of energy savings and potential peakdemand reductions) of electric-utility DSM programs. 


\section{INTRODUCTION}

\section{BACKGROUND}

Almost every issue of The Electricity Joumal, Prblic Utilities Fortnightly, and other publications dealing with electric utilities now contains articles on utility demand-side management (DSM) programs. Almost every resource plan prepared by utilities examines the energy savings and peak-demand reductions likely to occur because of the utility's DSM programs. And almost every p.oceeding before state regulatory commissions includes some discussion of the costs and benetits of utility DSM programs.

Although DSM is an increasingly important topic for utilities, their regulators, and others, little is known about the national scope, performance, and costs of such programs. The information we have on DSM programs is based primarily on anecdotes, samples of a few utilities, or estimates based on many assumptions. Faruqui et al. (1990) estimated that DSM programs cut annual electricity consumption by $1.3 \%$ and summer peak demand by $3.7 \%$ in 1990. Schweitzer, Hirst, and Hill (1991) conducted a survey of 24 utilities, representing about a third of total U.S. generating capacity; these utilities reported 1990 reductions of $0.8 \%$ for energy and $1.7 \%$ for peak demand. Moline (1992) mailed a survey to 2039 public-power utilities, of which 407 (about half of the respondents) reported operating DSM programs; these 407 utilities spent an average of $2.1 \%$ of their revenues on DSM programs. And Moskovitz, Nadel, and Geller (1991) obtained estimates of future DSM-progaam-induced demand and energy reductions from several utilities. But none of these studies was able to provide consistent and comprehensive coverage of the country as a whole.

Fortunately. the picture improved dramatically when the Energy Information Administration (EIA) published data from all U.S. electric utilities collected in its Form 861. EIA-861 is an annual census that collects basic information on utilities. EIA added Schedule $V$ io its 1989 form to ask about the peak-demand reductions (MW), energy reductions (GWh), and costs of utility DSM programs. In April 1992, ElA published summary statistics based on the utility responses to Scherlule V for 1989 and 1990 (Prete, Gordon, and Bromley 1992).

Of the roughly 3250 U.S. utilities that completed EIA-861, 872 reported operation of a DSM program. Of the 1,194 utilities with sales greater than $120 \mathrm{GWh}, 363$ reported running DSM programs in $1990,30 \%$ of the total. These 363 utilities reported spending $\$ 1.2$ billion on their DSM programs in 1990, up from $\$ 0.9$ billion in 1989 (Table 1). Estimates of energy savings and reduction in peak demand also showed substantial increases. Overall, utility DSM expenditures accounted for $0.7 \%$ of total revenues, while the reductions in energy and demand accounted for $0.6 \%$ and $4.9 \%$ of their respective 1990 totals. 
Table 1. Effects and costs of electric-utility DSM programs, 1989 and 1990)

\begin{tabular}{|c|c|c|c|}
\hline & $\begin{array}{l}\text { Potential peak } \\
\text { demand reduction } \\
(\mathrm{MW} \text { and } \% \text { ) }\end{array}$ & $\begin{array}{c}\text { Energy savings } \\
(\mathrm{G}: \text { Wh/year } \\
\text { and } \% \text { ad }\end{array}$ & $\begin{array}{l}\text { Program cost } \\
\text { (million } \$ \\
\text { and } \% \text { ) }\end{array}$ \\
\hline 1989 & $-\cdots$ & $14,80()$ & 890 \\
\hline \multicolumn{4}{|l|}{1990} \\
\hline Totals ${ }^{b}$ & 24,400 & 17,100 & 1,210 \\
\hline Investor-owned & 18,200 & 12,100 & 1,090 \\
\hline Public utilities & 6,200 & $5,(100)$ & 120 \\
\hline
\end{tabular}

athese percentages reflect, respectively, total U.S. peak demand, electricity generation, and electric revenues for 1990 .

bhese totals are based on the 363 utilities with annual sales greater than $120 \mathrm{GWh}$ that reported running a DSM program in 1990. Of these 363 utilities, 127 are investorowned, and the remaining 236 are public.

Source: Prete, Gordon, and Bromley (1992).

The investor-owned utilities (IOUs) accounted for 70 to $90 \%$ of these DSM totals, consistent with their national shares of total generating capacity, electricity sales, and revenues. The public utilities (sometimes called customer-owned utilities, which include federal, state, municipal, and cooperative utilities) reported larger percentage reductions in peak demand and energy, but smaller DSM expenditures as a percentage of revenues.

This report presents and interprets the 1990 data and the utility forecasts of their DSM program expenditures and energy and load impacts to the year 2000 , building on the analysis conducted by Prete et al. It also provides additional detail by analyzing the data in terms of utility ownership and state. Chapter 2 presents DSM-program expenditures for 1990. Chapters 3 and 4 discuss energy savings and potential peak-demand reductions, respectively. Chapter 5 discusses utility forecasts through the year 2000. And the final chapter presents caveats and conclusions derived from the ElA-861 data. But first, the remainder of this chapter describes the form itself, especially Schedule V.

\section{EIA-861}

All electric utilities are required by federal law to complete EIA-861. Schedule I collevets basic information on the utility's name and address. Schedule II collects information on utility ownership, suminer and winter peak loads, and sources and disposition of energy. Schedule III collects data on electric revenues. Schedule IV collects data on revenues, sales, and number of customers by sector and state in which the utility sells electricity. Schedule $V$ collects data on the effects and costs of the utility's DSM programs for the prior year and estimates for the next ten years (Fig. 1). Only utilities with annual sales greater than 120) 
GWh are required to complete Schedule V. Finally, Schedule VI collects data on nonutility power production.

EIA defines DSM as "a utility-administered program that is designed to reduce demand and/or electricity use. ... [L]oad building, load retention, and fuel substitution activities designed to increase demand and/or electricity use are excluded from the DemandSide Management Program" (EIA 1990).

DSM expenditures are those "incurred by the utility to achieve ine capacity and energy savings from the Demand-Side Management program. Expenditures incurred by consumers or third parties are to be excluded. The expenditures are to be reported in nominal dollars in the year in which they are incurred, regardless of when the savings occur."

Two types of estimates of reductions in peak load are requested. The first refers to the actual reduction in peak load caused by the utility's DSM program, specifically including the effects of direct load control, interruptible load, and conservation and other DSM. The second refers to the potential reduction in peak load, based on "the capability of reducing system demand ..., whether or not any reduction actually occurred ... ." This report examines potential, rather than actual, demand reductions. The demand and energy reductions are intended to reflect cumulative effects, which include the effects caused by all program participants from the program's inception through the present year, not just the participants in the current year.

Although it is tempting to compare utility costs with benefits, the results obtained would be misleading. As noted above, the DSM-program expenditures exclude costs borne by program participants and other nonutility parties. More important, the costs reflect utility expenditures in a particular year, whereas the reported energy savings and load reductions reflect the benefits of past as well as current program activities. Thus there is an unavoidable temporal mismatch between the data on costs and benefits. The Tennessee Valley Authority provides an interesting example of this phenomenon. TVA canceled its DSM programs in 1989, which accounts for its report to EIA of zero DSM-program expenditures in 1990. However, the program that TVA operated between the late 1970s and 1989 produced substantial energy savings and load reductions, as shown in Chapters 3 and 4. 


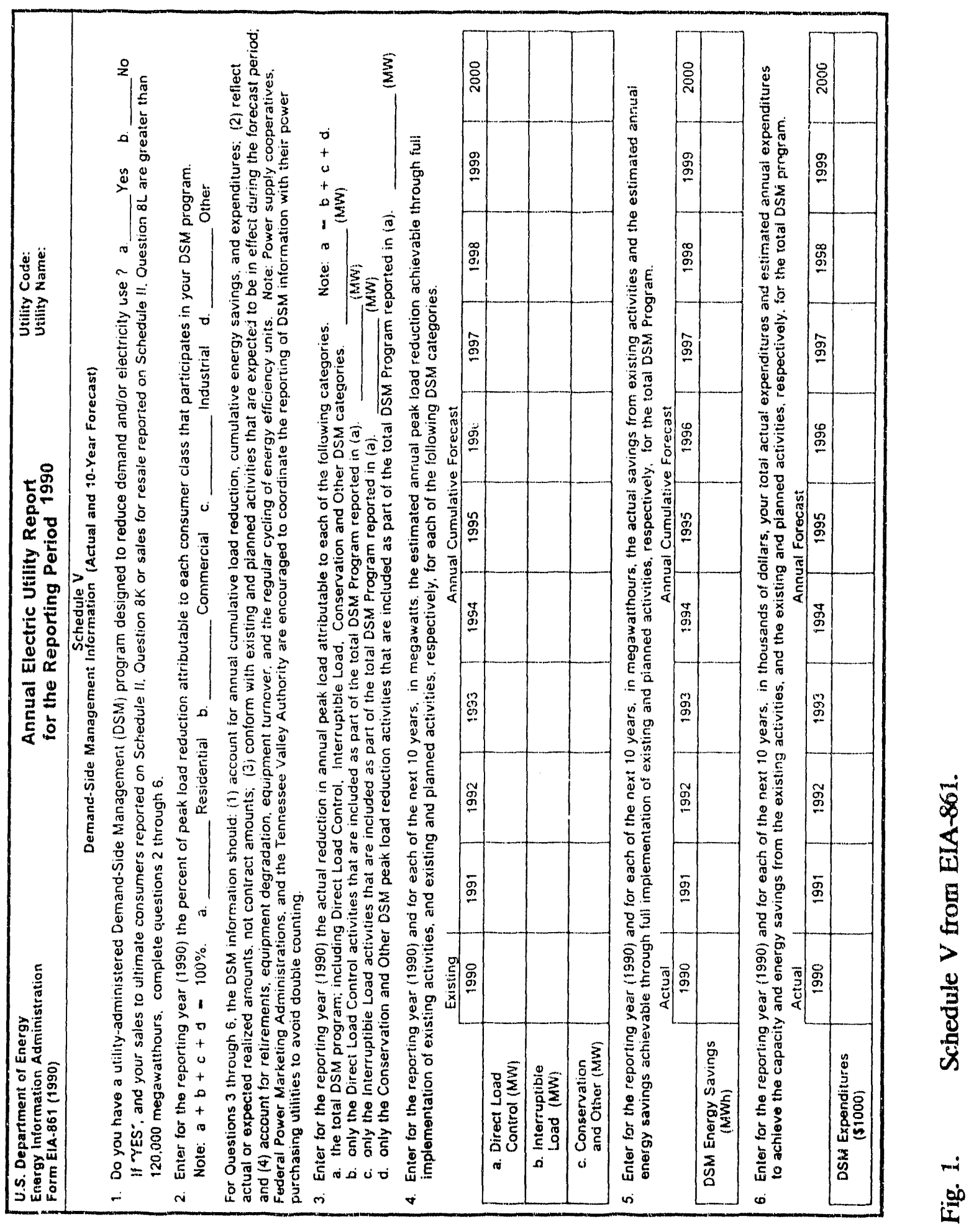




\section{DSM-PROGRAM EXPENDITURES}

I begin with expenditure data ecause it is probably more reliable than the data on demand and energy reductions. Estimates of energy savings and load reductions are confounded by definitions concerning net vs total effects, cumulative vs annual savings, the treatment of transmission and distribution losses, and the data and analytical methods used to estimate these effects (Hirst and Sabo 1991); see Chapters 3 and 6.

Although DSM-program expenditures totaled $\$ 1.2$ billion in 1990 (0.7\% of U.S. electric revenues), the distribution across the 363 utilities is highly skewed (Fig. 2). Only 31 utilities (less than $9 \%$ of the 363 ) accounted for three-fourths of the DSM-program costs that year. Almost $30 \%$ of these 363 utilities reported expenditures less than $0.1 \%$ of electric operating revenues; on the other hand, only $8 \%$ reported spending $2 \%$ or more on DSM programs (Fig. 3).

FRACTION OF U.S. UTILITY DSM EXPENSES

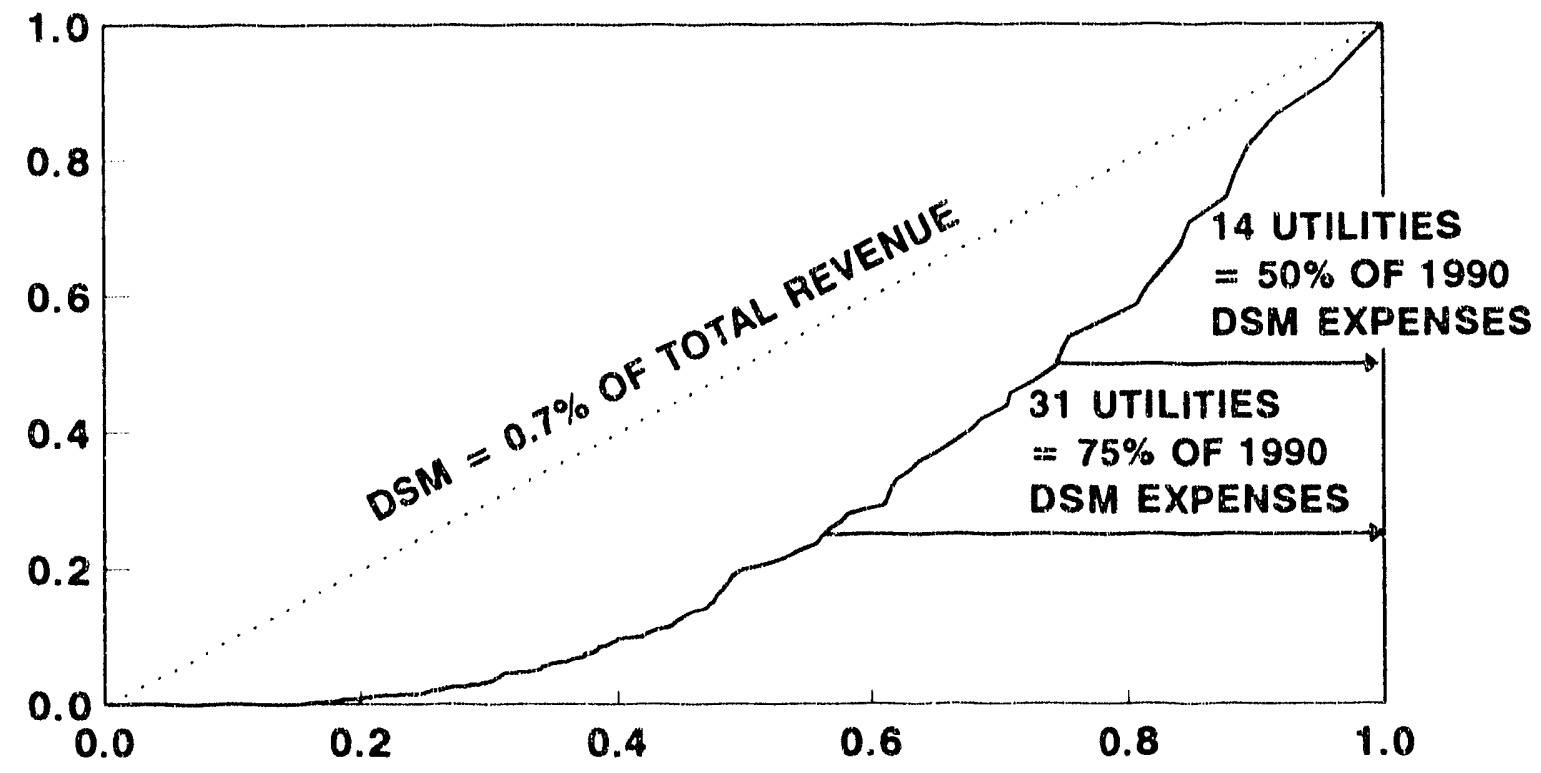

FRACTION OF U.S. UTILITY REVENUES

Fig. 2. 1990 DSM-program expenditures for the 363 electric utilities with DSM programs as a function of total revenues. The utilities are ordered in terms of increasing DSM expenditures. 
A statistical analysis of the fraction of revenues spent on DSM showed no correlation with annual revenues, a weak correlation with utility ownership $(p=0.20)$, and a stronger correlation with electricity price $(p=0.10)$. Investor-owned utilities spent 0.1 percentage points more on DSM than public utilities. And each $1 \mathrm{c} / \mathrm{kWh}$-increase in electricity price led to a 0.05 percentage point increase in DSM espenditures.

The data suggest that utilities on the east and west coasts plus a few in the midwest dominate in terms of DSM-program expenditures (Fig. 4). These results are only suggestive because many utilities sell electricity in more than one state. As examples, Duke Power and Carolina Power \& Light dominate in North and South Carolina; PacifiCorp sells electricity in seven states in the northwest. Because of the difficulties in assigning DSM-program costs to individual states for utilities that serve in more than one, I combined results for a few states [i.e., North and South Carolina, the District of Columbia (DC) and Maryland, and Oregon and Washington]. DSM expenditures exceeded $1 \%$ of revenues in Maine, Massachusetts, Vermont, Connecticut, Rhode lsland, DC and Maryland, North and South Carolina, Florida, Wisconsin, Washington and Oregon, and California.

Mitchell (1992) conducted a survey in 1991 to assess the status of integrated resource planning in each state. She defined "advanced" resource planning as one in which "significant DSM implementation is underway or has already occurred." All four of the states with DSM expenditures greater than $2 \%$ of revenues (Maine, Massachusetts, Rhode Island, and Wisconsin) were rated advanced by Mitchell. Ten of the twelve states rated advanced spent more than 1\% of revenues on DSM; only Minnesota and Nevada spent less (between 0.7 and $1.0 \%$ ). Thus, the utility reports to EIA and Mitchell's ratings are consistent with each other.

As shown in Fig. 2, a few utilities account for the vast majority of DSM expenditures. The top 25 utilities are listed in Table 2. One (Sacramento Municipal Utility District) is a public utility; the other 24 are investor-owned. These 25 utilities account for $68 \%$ of the national total DSM expenditure and for $37 \%$ of total U.S. electric revenues for 1990. Although the majority of these utilities are multibillion dollar companies, four (Puget Power, Central Maine Power, Commonwealth Electric, and Sacramento) are not.

Because public utilities are, on average, much smaller than investor-owned utilities, examination of the percentage of revenues spent on DSM programs (Table 3) reveals a different picture than that shown for absolute expenditures in Table 2. In terms of percentage expenditures on DSM, public-power dominates, with 14 of the top 25 utilities. On average, these 25 utilities spent $3.6 \%$ of revenues on their DSM programs, five times more than the national average of $0.7 \%$. 


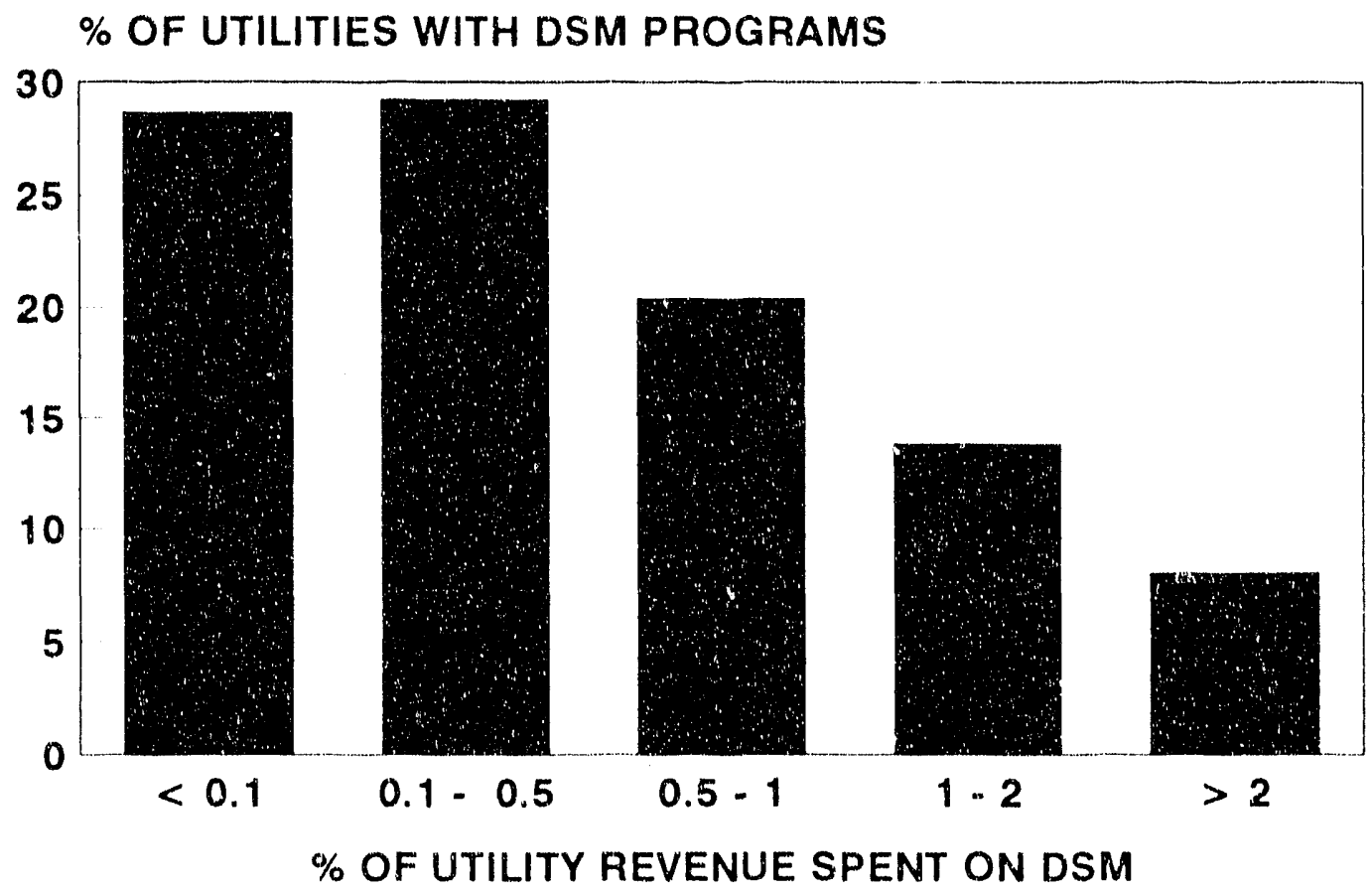

Fig. 3. Distribution of the 363 utilities with DSM programs by percentage of 1990 electric revenues spent on these programs. Both the mean value and the ratio of total expenditures to total revenues are $0.7 \%$.
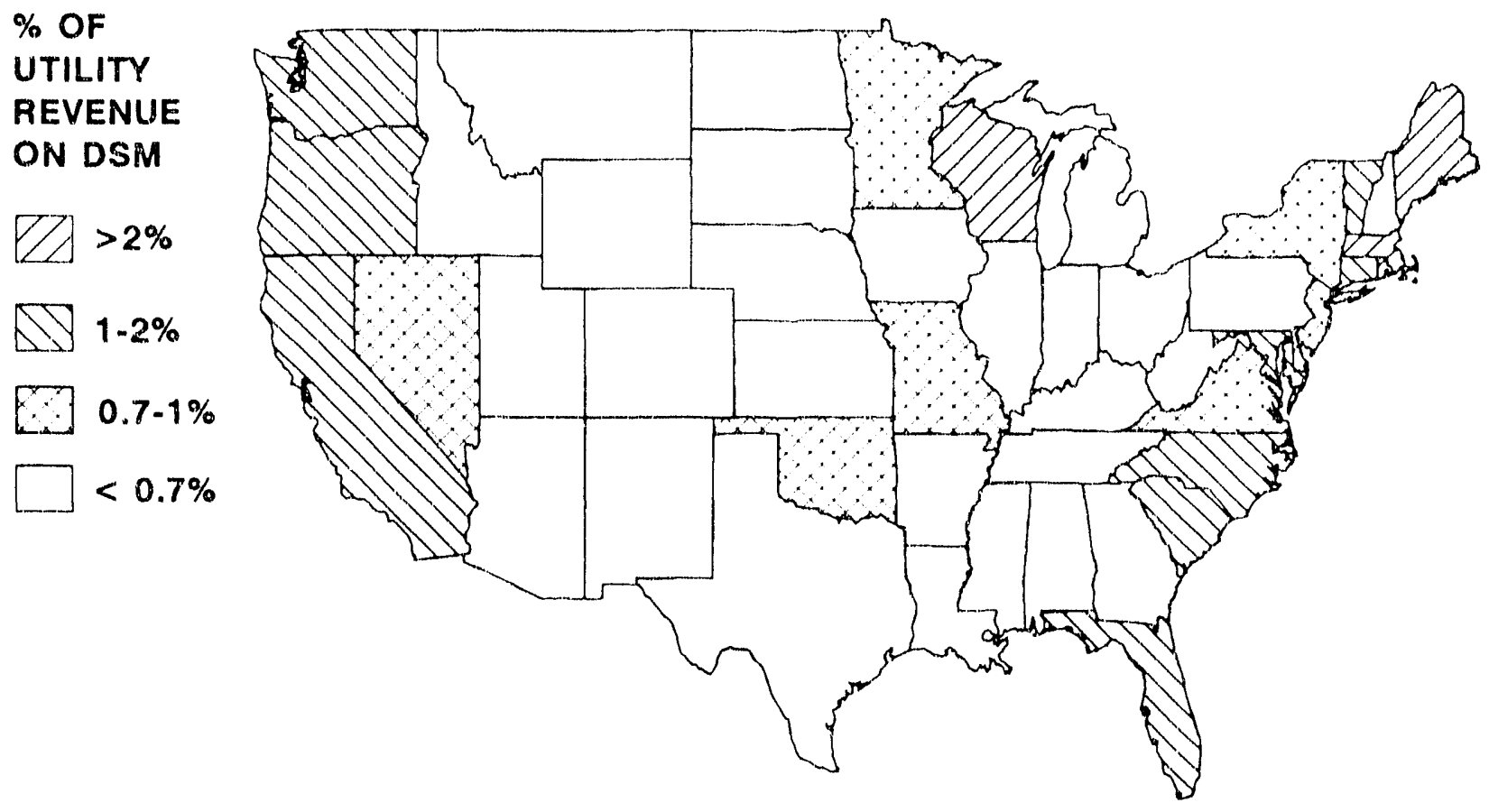

Fig. 4. The percentage of electric revenues spent on utility DSM programs by state. 
Table 2. The 25 utilities with the greatest 1990 expenditures on DSM

\begin{tabular}{|c|c|c|c|c|c|}
\hline Utility & State & $\begin{array}{l}\text { lov } \\
\text { (Yes, } \\
\text { No) }\end{array}$ & $\begin{array}{l}\text { DSM } \\
\text { expenditure } \\
\text { (million } \$ \text { ) }\end{array}$ & $\begin{array}{c}\text { Revenue } \\
\text { (million } \$ \text { ) }\end{array}$ & $\begin{array}{l}\text { \% revellue } \\
\text { on DSM }\end{array}$ \\
\hline $\begin{array}{l}\text { Pacific Gas \& Electric Company } \\
\text { Southern California Edison Co } \\
\text { Duke Power Campany } \\
\text { Florida Power Corporation } \\
\text { Wisconsin Electric Power Co } \\
\text { Florida Power \& Light Company } \\
\text { Massachusetts Electric Company } \\
\text { Connecticut Light \& Power Co } \\
\text { Long Island Lighting Company } \\
\text { Boston Edison Company } \\
\text { Consolidated Edison Co-Ny, Inc } \\
\text { Georgia Power Company } \\
\text { Puget Sound Power \& Light Co } \\
\text { Central Maine Power Company } \\
\text { Carolina Power \& Light Company } \\
\text { Virginia Electric \& Power Co } \\
\text { Commonwealth Electric Company } \\
\text { Public Service Electric \& Gas Co } \\
\text { Potomac Electric Power Company } \\
\text { Union Electric Company } \\
\text { PacifiCorp } \\
\text { Niagare Mohawk Power Corp } \\
\text { San Diego Gas \& Electric Co } \\
\text { Baltimore Gas \& Electric Co } \\
\text { Sacramento Municipal Utility Dist. }\end{array}$ & $\begin{array}{l}C A \\
C A \\
N C \\
F L \\
W I \\
F L \\
M A \\
C T \\
N Y \\
M A \\
\text { MY } \\
\text { GA } \\
\text { WA } \\
\text { ME } \\
\text { NC } \\
\text { VA } \\
\text { MA } \\
\text { NS } \\
D C \\
\text { MO } \\
\text { OR } \\
\text { NY } \\
C A \\
M D \\
C A\end{array}$ & $\begin{array}{l}\text { Yes } \\
\text { Yes } \\
\text { Yes } \\
\text { Yes } \\
\text { Yes } \\
\text { Yes } \\
\text { Yes } \\
\text { Yes } \\
\text { Yes } \\
\text { Yes } \\
\text { Yes } \\
\text { Yes } \\
\text { Yes } \\
\text { Yes } \\
\text { Yes } \\
\text { Yes } \\
\text { Yes } \\
\text { Yes } \\
\text { Yes } \\
\text { Yes } \\
\text { Yes } \\
\text { Yes } \\
\text { Yes } \\
\text { Yes } \\
\text { No }\end{array}$ & $\begin{array}{r}100.0 \\
62.2 \\
55.0 \\
49.8 \\
13.0 \\
42.7 \\
42.2 \\
39.3 \\
34.4 \\
29.5 \\
29.3 \\
28.3 \\
26.6 \\
25.4 \\
24.8 \\
23.0 \\
21.8 \\
21.5 \\
20.9 \\
20.0 \\
19.0 \\
17.0 \\
16.7 \\
16.5 \\
16.0\end{array}$ & $\begin{array}{r}7044 \\
6977 \\
3681 \\
1709 \\
1208 \\
4983 \\
1253 \\
2170 \\
2086 \\
1256 \\
4756 \\
4235 \\
935 \\
755 \\
2617 \\
3462 \\
354 \\
3332 \\
1412 \\
1939 \\
2184 \\
2646 \\
1355 \\
1684 \\
702\end{array}$ & $\begin{array}{l}1.4 \\
0.9 \\
1.5 \\
2.9 \\
3.6 \\
0.9 \\
3.4 \\
1.8 \\
1.7 \\
2.3 \\
0.6 \\
0.7 \\
2.8 \\
3.4 \\
0.9 \\
0.7 \\
6.2 \\
0.6 \\
1.5 \\
1.0 \\
0.9 \\
0.6 \\
1.2 \\
1.0 \\
2.3\end{array}$ \\
\hline Totals and average & & & 824.9 & 64740 & 1.8 \\
\hline
\end{tabular}


Table 3. The 25 utilities with the greatest 1990 percentage of expenditures on DSM

\begin{tabular}{|c|c|c|c|c|c|}
\hline Utility & State & $\begin{array}{l}\text { los } \\
(\text { Yes, } \\
\text { nos }\end{array}$ & $\begin{array}{c}n s h \\
\text { experditure } \\
\text { (millisn } \$ \text { ) }\end{array}$ & $\begin{array}{c}\text { Revenue } \\
\text { (millian } \$ \text { ) }\end{array}$ & $\begin{array}{l}\text { * revenue } \\
\text { on DSM }\end{array}$ \\
\hline $\begin{array}{l}\text { Minnkote Puwer Coop, Inc } \\
\text { Commonweal th Electric Company }\end{array}$ & $\begin{array}{l}\text { WD } \\
\text { MAR }\end{array}$ & $\begin{array}{l}\text { Ho } \\
\text { Yes }\end{array}$ & $\begin{array}{r}6.5 \\
21.8\end{array}$ & $\begin{array}{r}93 \\
354\end{array}$ & $\begin{array}{l}7.0 \\
6.2\end{array}$ \\
\hline $\begin{array}{l}\text { City of Detroit Lak s } \\
\text { Grant-Lafayet te Electric coop } \\
\text { Wortheast Oklahoma El Coop Inc } \\
\text { City of Burlington } \\
\text { City of Ashlarut } \\
\text { Wisconsin Electric Power } \mathrm{Cc}^{a}\end{array}$ & $\begin{array}{l}\text { WH } \\
W I \\
O K \\
V T \\
O R \\
W I\end{array}$ & $\begin{array}{l}\text { No } \\
\text { No } \\
\text { No } \\
\text { Ho } \\
\text { No } \\
\text { Yes }\end{array}$ & $\begin{array}{l}0.2 \\
0.5 \\
1.0 \\
1.5 \\
0.2 \\
43.0\end{array}$ & $\begin{array}{r}5 \\
10 \\
22 \\
37 \\
7 \\
1208\end{array}$ & $\begin{array}{l}4.8 \\
4.7 \\
4.4 \\
4.2 \\
3.6 \\
3.6\end{array}$ \\
\hline $\begin{array}{l}\text { Warragansett Electic Compariy } \\
\text { Polk-Burnett Electric Coop } \\
\text { City of Eugene } \\
\text { Massachusetts Electric Company }\end{array}$ & $\begin{array}{l}R I \\
W 1 \\
\text { dKk } \\
M A\end{array}$ & $\begin{array}{l}\text { Yes } \\
\text { We } \\
\text { No } \\
\text { Yes }\end{array}$ & $\begin{array}{r}14.5 \\
0.4 \\
3.0 \\
42.2\end{array}$ & $\begin{array}{r}412 \\
10 \\
186 \\
1253\end{array}$ & $\begin{array}{l}3.5 \\
3.5 \\
3.5 \\
3.4\end{array}$ \\
\hline Central Maine Power Company & ME & Yes & 25.4 & 755 & 3.4 \\
\hline $\begin{array}{l}\text { Federated Rural Electric Assn } \\
\text { aranite State Electric Comf thy } \\
\text { BARC Electric Cooperative, InC } \\
\text { Wisconsin Power \& Light Co } \\
\text { Cambridge Electric Light co } \\
\text { Florida Power Corporation" }\end{array}$ & $\begin{array}{l}\text { MW } \\
\text { WH } \\
\text { VA } \\
\text { WI } \\
\text { MA } \\
\text { FL. }\end{array}$ & $\begin{array}{l}\text { No } \\
\text { Yes } \\
\text { No } \\
\text { Yes } \\
\text { Yes } \\
\text { Yes }\end{array}$ & $\begin{array}{r}0.2 \\
1.7 \\
0.3 \\
14.8 \\
3.4 \\
49.8\end{array}$ & $\begin{array}{r}6 \\
52 \\
9 \\
467 \\
116 \\
1709\end{array}$ & $\begin{array}{l}3.3 \\
3.3 \\
3.2 \\
3.2 \\
2.9 \\
2.9\end{array}$ \\
\hline $\begin{array}{l}\text { Puget Sound Power \&, Llght co } \\
\text { Yellowstone Valley Elec Coop Inc } \\
\text { Tri-County Electric Cooo, ine } \\
\text { Pud Wo } 1 \text { of Snohomish County } \\
\text { Lake Region Coop Elec Assn } \\
\text { Western Massachusetts Elec Cu }\end{array}$ & $\begin{array}{l}\text { WA } \\
\text { MY } \\
\text { IL } \\
\text { WA } \\
\text { MH } \\
\text { MA }\end{array}$ & $\begin{array}{l}\text { Yes } \\
\text { Ho } \\
\text { No } \\
\text { Ho } \\
\text { No } \\
\text { Yes }\end{array}$ & $\begin{array}{r}26.6 \\
0.2 \\
0.6 \\
5.9 \\
0.4 \\
9.5\end{array}$ & $\begin{array}{r}935 \\
8 \\
21 \\
231 \\
15 \\
375\end{array}$ & $\begin{array}{l}2.8 \\
2.6 \\
2.6 \\
2.5 \\
2.5 \\
2.5\end{array}$ \\
\hline Totals and average & & 11 & 273.5 & 8197 & 3.6 \\
\hline
\end{tabular}

aThese six utilities are in both Tables 2 and 3. 


\section{DSM-PROGRAM ENERGY SAVINGS}

The results presented in this and the following chapter should be viewed cautiously for several reasons. First, utilities may use different definitions for DSM programs. I:or example, Carolina Power \& Light and Florida Power Corporation include the energy provided by cogenerators in their DSM-program totals; most other utilities do not. Some utilities might have included the effects of their load-building programs even though the EIA instructions clearly stated that they should not.

Second, utilities use different methods to estimate the effects of their DSM programs; in general, engineering estimates are higher than estimates based on billing data or loadresearch data (Nadel and Keating 1991).

Third, utilities might report estimates at the customer meter or at the generator busbar; these estimates differ by roughly 5 to $15 \%$ because of losses in the transmission and distribution system.

Fourth, some utilities might report total savings rather than net savings. Net savings are the reductions in electricity use and demand that can be attributed directly to the program, whereas total savings are the reductions in electricity use and demand experienced by program participants (Hirst and Sabo 1991).

Finally, some utilities might have reported annual savings instead of the cumulative savings requested by EIA. Messenger (1992) notes that the Califor ina utilities reported annual savings; he suggests that the correct number for Southern California Edison is 4,100 $\mathrm{GWh}$, not the $610 \mathrm{GWh}$ reported by the company.

The distribution across utilities in energy savings (Fig. 5) is even more skewed than is the distribution of program expenditures. Here, only 13 utilities account for three-fourths of the national savings. Almost two-thirds of the 363 utilities reported energy savings less than $0.1 \%$ of 1990 generation. And only $7 \%$ of these utilities reported cutting energy use by $2 \%$ or more.

As shown in Fig. 5, a very few utilities account for most of the energy savings. The top 25 are listed in Table 4. Four of these utilities are publics, and the remaining 21 are IOUs. Two of the pub'ic-power utilities are federal agencies, the Tennessee Valley Authority and the Bonneville Power Administration, which sell electricity to almost 300 public-power utilities. Altogether, these 25 utilities accounted for $86 \%$ of the total DSM-program energy savings in 1990, compared with only $27 \%$ of total generation. On average, these utilities cut energy use by $2.1 \%$, more than triple the national average of $0.6 \%$. 


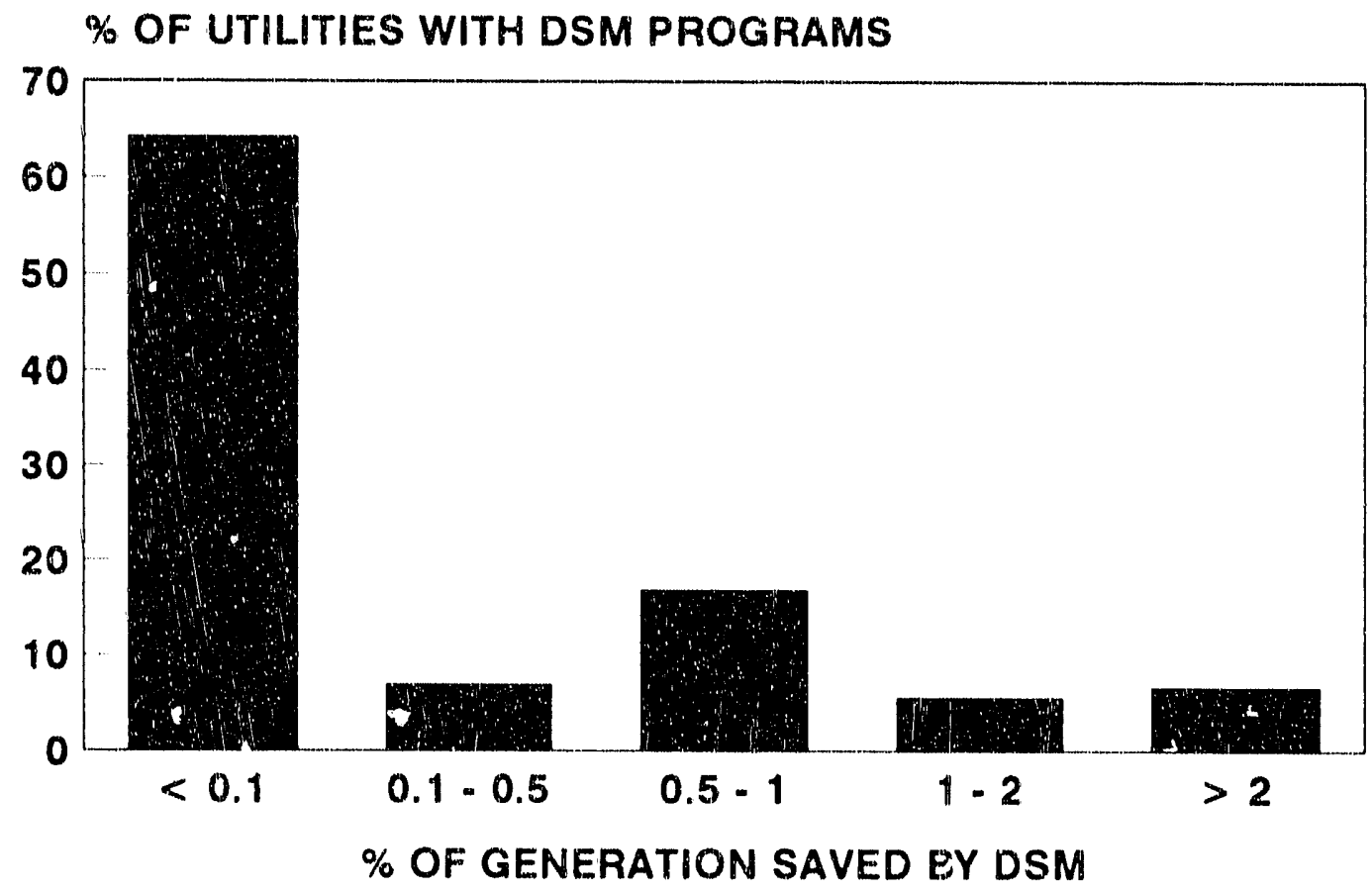

Fig. 5. Distribution of the 363 utilities with DSM programs by percentage of total 1990 generation saved by these programs. The mean value is $0.5 \%$ of generation saved, and the ratio of total energy savings to total generation is $0.6 \%$. 
Table 4. The 25 utilities with the largest 1990 energy savings

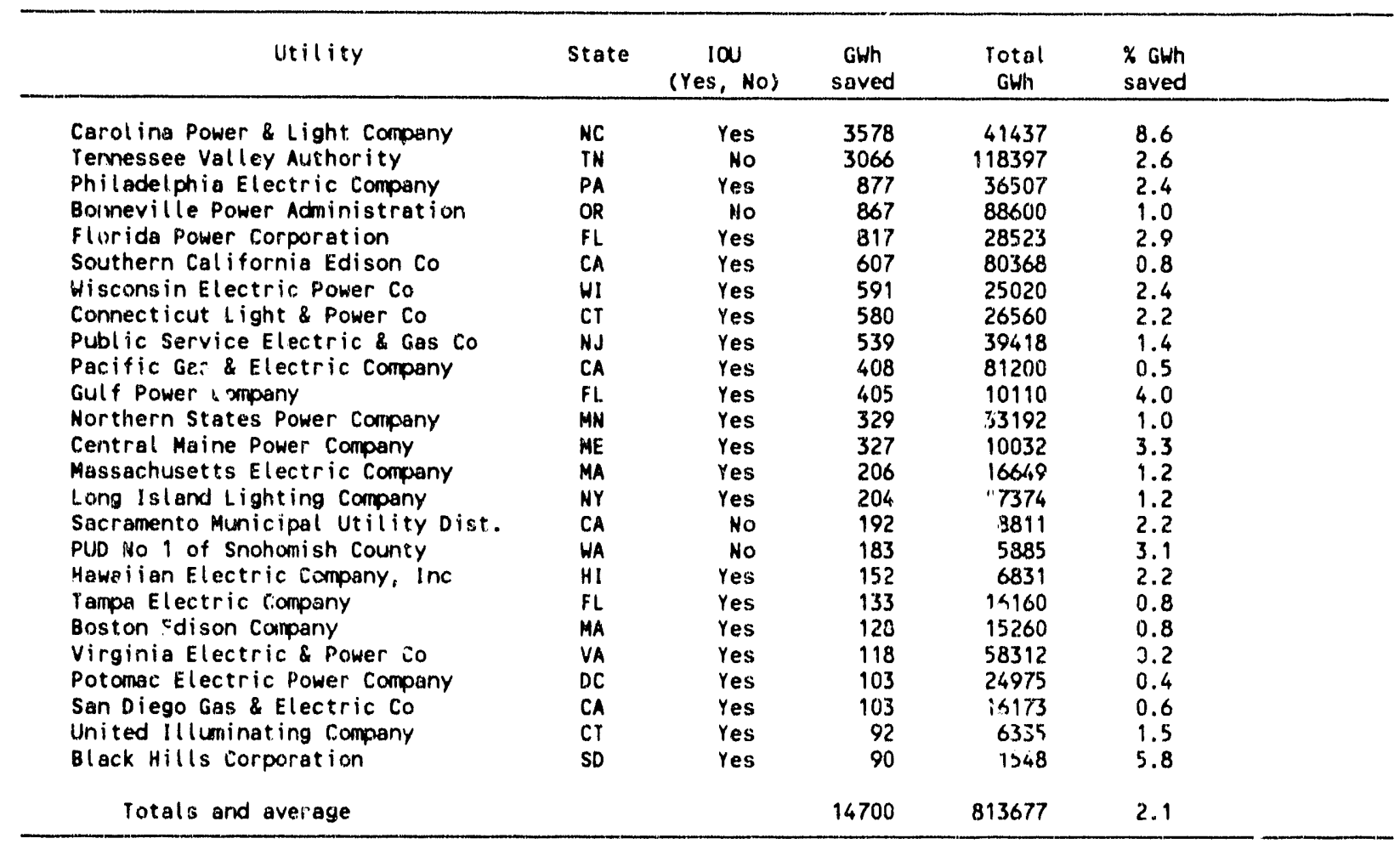




\section{DSM-PROGRAM PEAK DEMAND REDUCTIONS}

The distribution across utilities in the potential demand reduction at the time of system peak is much less skewed than for either expenditures or energy savings (Fig. 6). This difference reflects the fact that, traditionally, utility DSM programs have emphasized reductions in peak demand rather than overall improver.ents in customer energy efficiency. Whereas only 13 utilities account for $75 \%$ of the 1990 energy reduction, 40 utilities account for $75 \%$ of the peak demand reduction. Whereas $64 \%$ of the 363 utilities reported energy savings less thai $3.1 \%$ of generation, only $6 \%$ reported demand reductions less than $0.1 \%$ of peak demand. Almost $50 \%$ of the utilities reported potential reductions geater than $5 \%$ of peak demand.

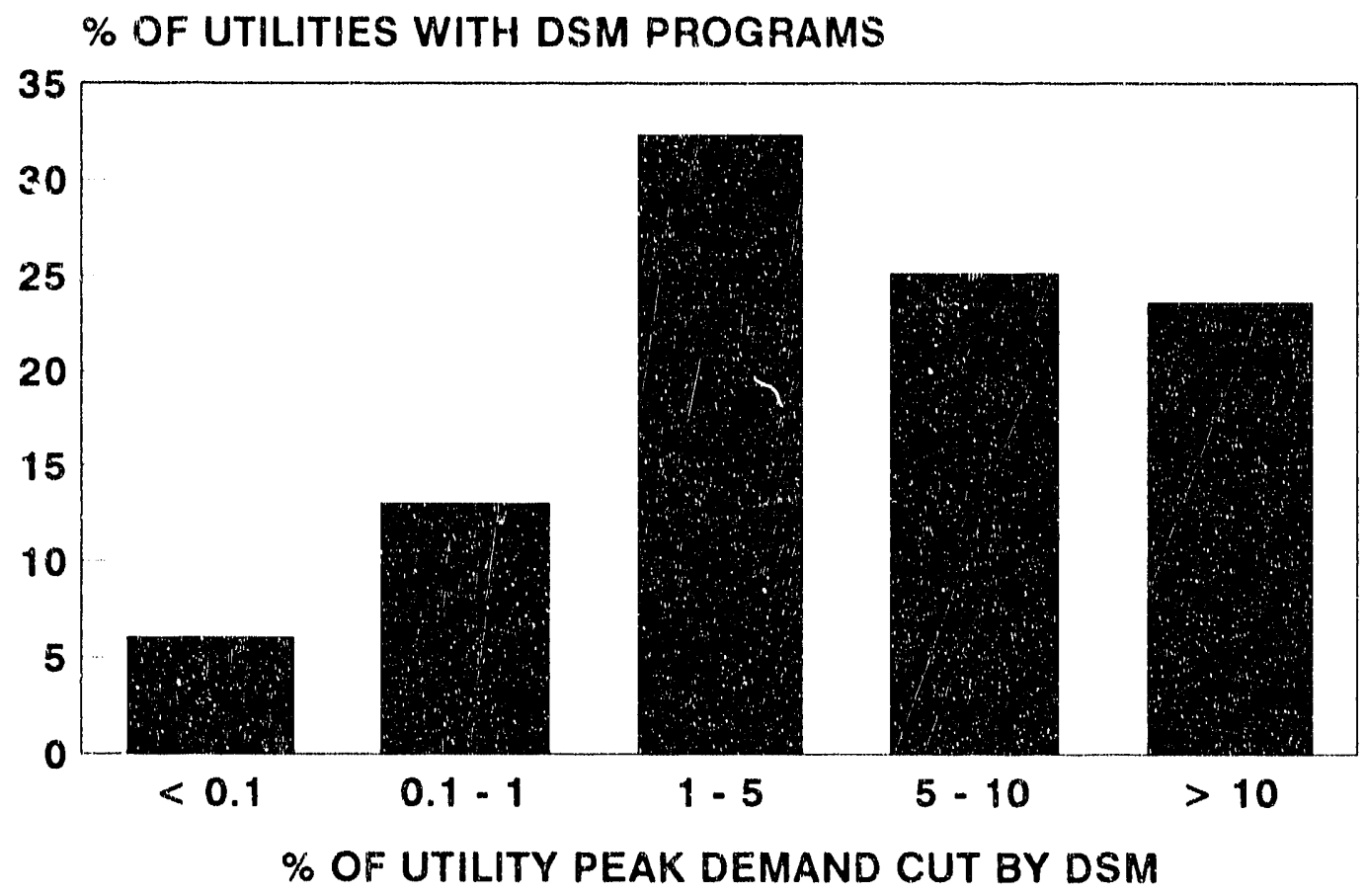

Fig. 6. Distribution of the 363 utilities with DSM programs by percentage of total 1990 peak-demand savings by these programs. The mean value is $7.9 \%$ of system peak, and the ratio of total potential demand reduction to total peak is $4.9 \%$. 
Table 5 lists the top 25 utilities in terms of potential demand reductions. Twenty of these utilities are investor-owned, and three of the five publics are federal wulities. Altogether, these 25 utilities account for $63 \%$ of the total demand reduction and $40 \%$ of the summer peak. On average, these 25 utilities cut peak demand by $10.1 \%$, double the national average of $4.9 \%$.

Table 5. The 25 utilities with the greatest 1990 peak-demand reductions

\begin{tabular}{|c|c|c|c|c|c|c|}
\hline \multirow[t]{2}{*}{ utility } & \multirow[t]{2}{*}{ State } & \multirow{2}{*}{$\begin{array}{c}100 \\
\text { (Yes, No) }\end{array}$} & \multirow{2}{*}{$\begin{array}{c}\text { MW } \\
\text { saved }\end{array}$} & \multicolumn{2}{|c|}{ Peak demand } & \multirow{2}{*}{$\begin{array}{r}\% \mathrm{Mh} \\
\text { saved } \\
\end{array}$} \\
\hline & & & & MW-Winter & MW-Summer & \\
\hline Southern California Edison Co & $C A$ & Yes & 1494 & 12405 & 17647 & 8.5 \\
\hline Texas Utilities Electric co & $T X$ & Yes & 1363 & 15620 & 18007 & 7.6 \\
\hline Carolina Power \& Light Company & NC & Yes & 1248 & 7205 & 8134 & 15.3 \\
\hline Tennessee Valley Authority & TN & Ho & 1182 & 18451 & 21749 & 5.4 \\
\hline Florida Power Corporation & $\mathrm{FL}$ & Yes & 1079 & 5026 & 5946 & 18.1 \\
\hline Houston Lighting \& Power Co & $T x$ & Yes & 1070 & 8302 & 11150 & 9.6 \\
\hline Florida Polver \& Light Company & $\mathrm{FL}$ & Yes & 970 & 10047 & 13754 & 7.1 \\
\hline Bonneville Power Administration & DR & No & 878 & 18034 & 16316 & 4.9 \\
\hline Duke Power Company & NC & Yes & 742 & 11607 & 13514 & 5.5 \\
\hline Georgia Power Company & GA & Yes & 629 & 8977 & 13196 & 4.8 \\
\hline A l abama Power Company & AL & Yes & 444 & 6936 & 8878 & 5.0 \\
\hline Nor thern States Power Company & MN & Yes & 444 & 5341 & 6733 & 6.6 \\
\hline Oklahoma Gas \& Electric Co & OK & Yes & 402 & 3480 & 4810 & 8.4 \\
\hline Western Area Power Administration & $A Z$ & No & 379 & $\ldots$ & - & $\cdots$ \\
\hline Pacificorp & OR & Yes & 353 & 7735 & 6713 & 4.6 \\
\hline Oglethorpe Power Corporation & GA & No & 342 & 2038 & 3203 & 10.7 \\
\hline Philadelphia Electric Company & PA & Yes & 319 & -. & $\cdots$ & -. \\
\hline Tampa El ectric Comparyy & $\mathrm{FL}$ & Yes & 303 & 2052 & 2630 & 11.5 \\
\hline Minnkota Fower Coop, inc & ND & No & 270 & 504 & 328 & 53.6 \\
\hline Public Service Electric \& Gas Co & NJ & Yes & 265 & 5817 & 8497 & 3.1 \\
\hline Potomac E ectric Power Company & $D C$ & Yes & 245 & 3947 & 5442 & 4.5 \\
\hline lowa Electric Light \& Power Co & IA & Yes & 238 & 747 & 1005 & 23.7 \\
\hline Pennsylvania Power \& Light Co & PA & Yes & 232 & 5661 & 4959 & 4.1 \\
\hline Connecticut Light \& Power co & CT & Yes & 218 & 3765 & 4015 & 5.4 \\
\hline Arkansas Power \& Light Company & $A R$ & Yes & 217 & 2492 & 3993 & 5.4 \\
\hline Totals and average & & & 15326 & 166189 & 200619 & 10.1 \\
\hline
\end{tabular}




\section{UTILITY FORECASTS, 1991-2000}

EIA requested estimates of future DSM-program expenditures and effects for the years 1991 through 2000 in Schedule V. I normalized these utility reports with EIA's projections of growth in electricity use and prices from 1990 through 2000 (EIA 1991). EIA expects electricity use to increase at an average annual rate of $1.9 \%$ during the $1990 \mathrm{~s}$ and electricity price to remain unchanged in real terms.

Assuming an average inflation rate of $4.5 \% / y e a r$ during the 1990s, these utility forecasts show growth in DSM expenditures from $\$ 1.2$ billion in 1990 to $\$ 2.0$ billion in 2000 (in 1990 dollars), an average growth of $5 \% / y e a r$. Compared to projected revenues, DSM budgets are expected to increase from $0.7 \%$ in 1990 to $1.5 \%$ in 2000 (Fig. 7).

Energy savings are expected to increase from $17,100 \mathrm{GWh}$ in 1990 to $78,500 \mathrm{GWh}$ in 2000 , with a relative growth from $0.6 \%$ to $2.2 \%$ of total generation. Potential demand reductions are also expected to increase, from $24,400 \mathrm{MW}$ in 1990 to $55,800 \mathrm{MW}$ in 2000, with a relative growth from $4.9 \%$ to $9.3 \%$ of peak demand. As shown in Fig. 7, the increase in energy effects is much greater than for either expenditures or demand reductions.

I believe that these utility forecasts, made in early 1991, underestimate future DSM expenditures and effects. Utility resource plans often show increases in estimates of future DSM-program effects as the utility gains experience in running DSM programs. Consider the following examples. Georgia Power reported zero energy savings for each year, 1990 through 2000, in its EIA-861 submission (although it reported nonzero DSM-program expenditures and peak-demand reductions). However, its 1992 resource plan shows substantial energy savings expected from its DSM programs, reaching $580 \mathrm{GWh}$ in 1995 and $1,680 \mathrm{GWh}$ in 2000 (Georgia Power 1992). Duke Power's ElA-861 responses also showed zero energy savings throughout the 1990s. However, its 1992 resource plan showed rapidly increasing energy savings caused by its DSM programs: $14 \mathrm{GWh}$ in 1992, $269 \mathrm{GWh}$ in 1993, $664 \mathrm{GWh}$ in 1994, and almost 2,000 GWh in 1997 (Duke Power 1992). The Los Angeles Department of Water and Power (the nation's largest municipal utility) reported having no DSM program on the 1990 EIA-861. Since then, however, the utility has begun a rapidly expanding DSM program (Association of Demand-Side Management Professionals 1992). The utility plans to spenci $\$ 500$ million on DSM programs during the next ten years. PacifiCorp (1992) provides a less dramatic example. Its 1992 resource plan shows an estimated energy savings of $239 \mathrm{GWh}$ in $1993,10 \%$ higher than the value reported to EIA. 


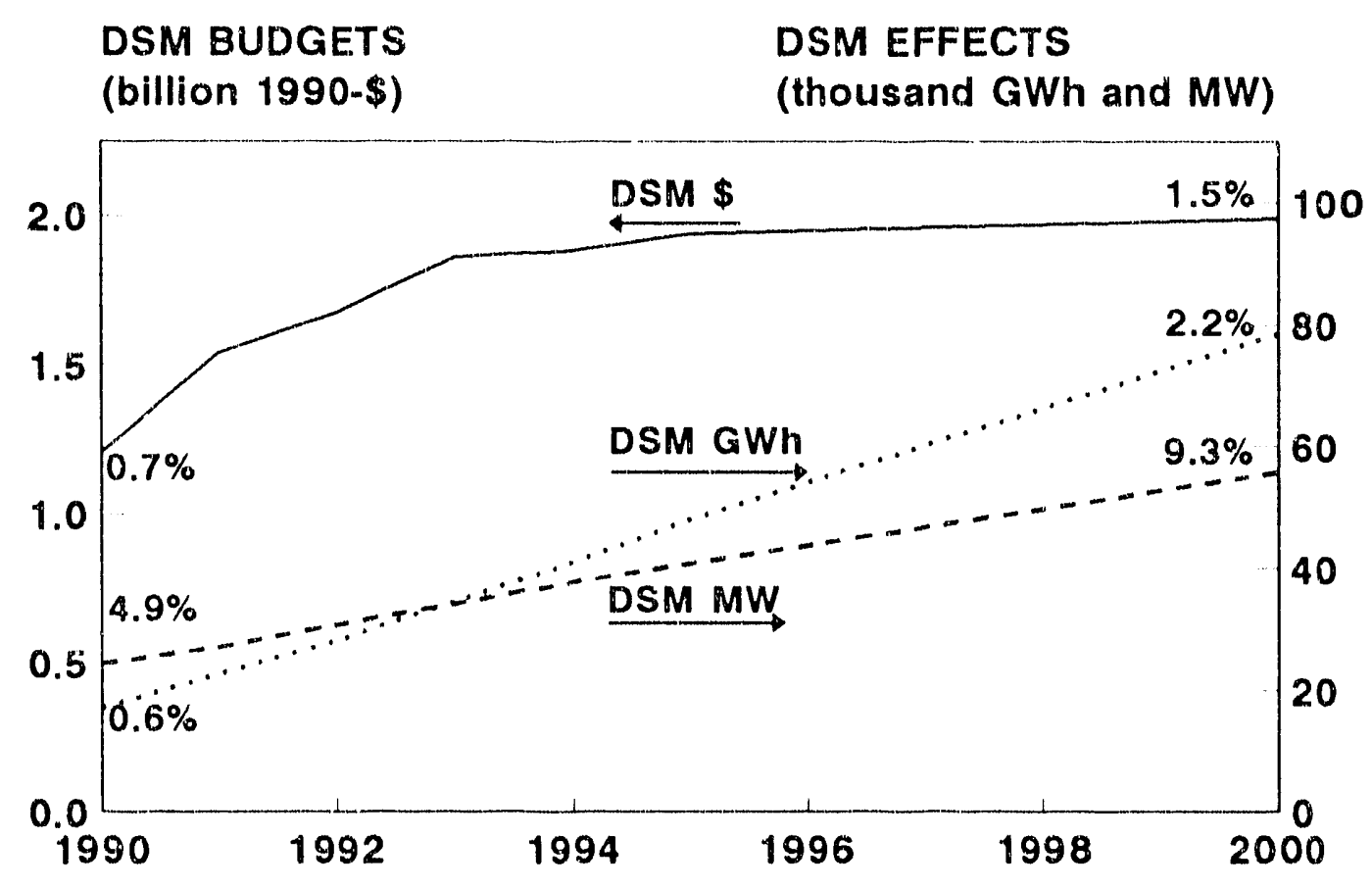

Fig. 7. Utility forecasts of DSM-program expenditures and effects from 1990 through 2000 in absolute and relative terms. The percentage figures are relative to the 1990 and 2000 national totals for annual electric-utility revenues, sales, and peak demands. 


\section{CAVEATS AND CONCLUSIONS}

\section{CAVEATS}

Because Schedule $V$ is a new form, some of the responses are likely to be ambiguous or incorrect. For example, although EIA asked utilities to report "cumuiaitive" energy savings, the word cumulative was not defined. Cumulative effects are the changes in electricity use and demand caused by all of a program's participants from the program's inception through the current year (Hirst and Sabo 1991). Some utilities might have reported annual effer:ts, which are the changes in electricity use and demand caused by a program's activities during a given year. This type of error would underestimate DSM-program effects.

On the other hand, possible double-counting would overestimate effects. EIA encouraged "power supply cooperatives, federal power marketing administrations, and the Tennessee Valley Authority ... to coordinate the reporting" of DSM program information, but there is no assurance that this occurred.

Estimates of program effects can differ substantially depending on the point in the system at which they are estimated, the data and analytical methods used to derive these estimates, and the definition of program effect that is used. Estimates of peak-demand reduction at the generation level are likely to be 10 to $15 \%$ higher than estimates at the customer meter; for energy savings, the difference is likely to be 5 to $10 \%$. Reliance on measured electricity use (either monthly billing data or time-of-use data) coupled with sophisticated statistical methods is likely to yield estimates of energy savings that are lower (and more accurate) than those based on simple engineering calculations. And estimates that focus on the effects of the program in question and therefore exclude the effects of market forces, government efficiency standards, and nonutility programs are likely to be lower than estimates that take credit for these other influences on customer electricity use.

In some cases, utilities left blanks. For example, some utilities reported DSM-program expenditures for 1990 but not for future years, which has the effect of underestimating DSMprogram costs. (I corrected for this in Chapter 5 by excluding those utilities from the analysis of growth in expenditures from 1990 through 2000.) Several utilities did not report estinlates of program-induced energy savings, although subsequent resource plans from these companies show substantial commitments to energy efficiency.

Developing state totals is complicated by the fact that many utilities sell electricity in more than one state. For example, Potomac Electric Power Company serves customers in the District of Columbia and in Maryland. Assigning all its activities to DC leads to a $140 \%$ overestimate of the DC total utility revenue and a $21 \%$ underestimate for Maryland. When 
DC and Maryland are combined, the EIA-861 results agree very closely with the state totals reported in the Electric Power Monhly (EIA 1992a).

\section{CONCLUSIONS}

As of 1990, the costs and effects of utility DSM programs were small. These prograrns cut peak demand by $4.9 \%$ and energy use by $0.6 \%$; utilities spent $0.7 \%$ of total revenues that year on such programs. These averages, however, hide a tremendous amount of variation across utilities in both the absolute and relative effects of their DSM programs. Specifically, although 363 (of 1,194) utilities reported running DSM prograrns in 1990, the "top" 50 utilities account for three-fourths of these costs and effects (Fig. 8). Thus, the majority of U.S. utilities are running what could at best be considered modest DSM programs.

However, projected growth for the 1990)s is very rapid. DSM budgets are expected to nearly triple, peak-demand reductions are expected to more than double, and energy savings are expected to increase more than four-fold (Fig. 7). Relative to the expected increases in electricity use and revenues, DSM effects and costs also increase, but at slower rates.

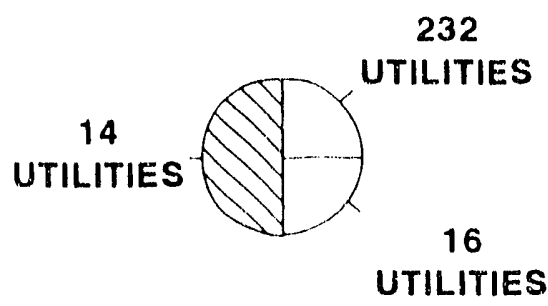

DSM PROGRAM COST

PROGRAM COST

323

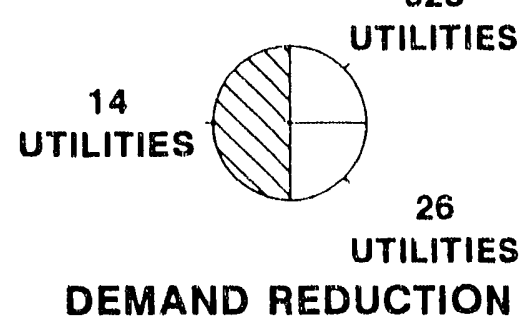

ENERGY SAVINGS

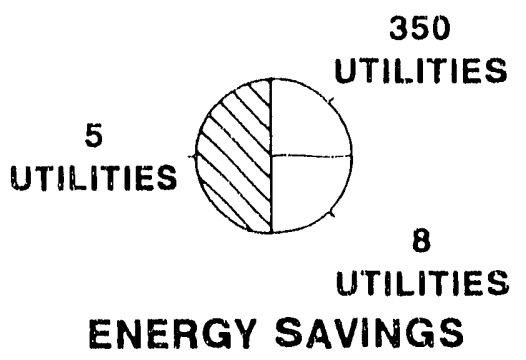

Fig. 8. Distributions across the 363 utilities with DSM programs in 1990 of totals for program costs, peak-demand reductions, and energy savings. For example, only 14 utilities account for $50 \%$ of the total demand reduction caused by DSM programs in 1990. 
The differences in DSM budgets and effects across utilities is astonishing. To some extent this variation is a function of utility ownership and location, with investor-owned utilities and those in New England and the west coast more likely to sperd a larger fraction of revenues on DSM programs than other utilities are.

There are limitations in the 1990 data reported on EIA's form 861, an unavoidable consequence of any new data-collection instrument. Nevertheless, these data provide a comprehensive and useful picture of 1990 activities and plans through the year 2000. EIA (1992b) is expanding the scope of Schedule V. The draft 1992 form includes questions on DSM-program effects by customer class and breakdowns by type of DSM prograin (energy efficiency, load management, interruptible load, load building, and other programs). These additional questions should yield a much more detailed picture of utility DSM programs and their effects.

\section{ACKNOWLEDGMENTS}

1 appreciate the help from Lawrence Prete, Susan Smith, and others in EIA who provided the data to me and helped interpret them. I am also grateful to Robert Jeffrey and Tom Devlin (SAIC, a iontractor to EIA) for the same reasons. I thank Douglas Bauer, Charles Goldman, Michael Messenger, Cynthia Mitchell, Barry Moline, Diane Pirkey, Lawrence Prete, Martin Schweitzer, and Richard Tempchin for their helpful comments on a draft of this report. I also thank Fred O'Hara for editing the report and Ethel Schorn for assembling and shepherding the final report through ORNL clearances. 


\section{REFERENCES}

Association of Demand-Side Management Professionals 1992, "Traditional Los Ang.les Embraces DSM Ethic," Strategies 3(2), 1-2, Spring.

Duke Power Company 1992, Integrated Resource Plan 1992, Charlotte, NC, April.

Energy Information Administration 1990, "Annual Electric Utility Report for the Reporting Period 1990," EIA-861, U.S. Department of Energy, Washington, DC.

Energy Information Administration 1991, Annual Outlook for U.S. Electric Power 1991, Projections Through 2010, DOE/EIA-()474(91), U.S. Department of Energy, Washington, DC, July.

Energy Information Administration 1992a, Electric Power Monthly, DOE/EIA-(0226(92/(03), U.S. Department of Energy, Washington, DC, March.

Energy Information Administration 1992b, "Annual Eleciric Utility Report for the Reporting Period 1992," Draft, EIA-861, U.S. Department of Energy, Washington, DC, May.

A. Faruqui, K. Seiden, R. Benjamin, J. H. Chamberlin, and S. D. Braithwait 1990, Impact of Demand-Side Management on Future Customer Electricity Demand: An Update, EPRI CU6953, Electric Power Research Institute, Palo Alto, CA, and Edison Electric Institute, Washington, DC, September.

Georgia Power Company 1992, 1992 Integrated Resource Plan, Atlanta, GA, January.

E. Hirst and C. Sabo 1991, Electric-Utility DSM Programs: Terminology and Reporting Formats, ORNL/CON-337, Oak Ridge National Laboratory, Oak Ridge, TN, October.

M. Messenger 1992, personal communication, California Energy Commission, Sacramento, CA, June 9.

C. Mitchell 1992, "Integrated Resource Planning Survey: Where the States Stand," The Electricity Joumal 5(4), 10-15, May.

B. Moline 1992, Demand-Side Management in Public Power, The Quiet Revolution, Findings from a Survey of Publicly Owned Utilities, American Public Power Association, Washington, DC, January. 
D. Moskovitz, S. Nadel, and H. Geller 1991, Increasing the Efficiency of Electricity Production and Use: Barriers and Strategies, American Council for an Energy-Efficient Economy, Washington, DC, November.

S. Nadel and K. Keating 1991, "Engineering Estimates vs Impact Evaluation Results: How Do They Compare and Why," pp. 24-33 in Energy Program Evaluation: Uses, Methods, and Results, Proceedings of the 1991 International Energy Program Evaluation Conference, CONF-910807, August.

PacifiCorr 1992, Balanced Planning for Growth, Resource and Market Planning Program, RAMPP-2, Portland, OR, May.

L. Prete, J. Gordon, and L. Bromley 1992, "Electric Utility Demand-Side Management," Electric Power Monthly, 19-33, DOE/EIA-0226(92/04), U.S. Department of Energy, Washington, DC, April.

M. Schweitzer, E. Hirst, and L. Hill 1991, Demand-Side Managemes:t and Integraied Resource Planning: Findings from a Survey of 24 Electric Utilities, ORNL/CON-314, Oak Ridge National Laboratory, Oak Ridge, TN, February. 


\section{INTERNAL DISTRIBUTION}

1. D. Bauer

2. V. D. Baxter

3. L. Berry

4. D. S. Bjornstad

5. M. A. Brown

6. R. S. Carlsmith

7. F. C. Chen

8. J. Christian

9. G. Courville

10. P. D. Fairchild

11. W. Fulkerson

12. M. B. Gettings

13. C. W. Hagan

14. L. J. Hill

15. E. Hillsman

16. E. Hirst

17. P. J. Hughes

18. C. R. Kerley

19. J. O. Kolb

20. M. A. Kuliasha
21. R. Lee

22. P. Leiby

23. J. M. MacDonald

24. V. C. Mei

25. W. R. Mixon

26. S. Purucker

27. D. E. Reichle

28. D. T. Rizy

29. M. Schweitzer

30. R. B. Shelton

31. J. N. Stone

32. J. Van Dyke

33. J. M. Veigel (ORISE)

34. D. L. White

35. 'T. J. Wilbanks

36. ORNL Patent Office

37. Central Research Office

38. Document Reference Section

39. Laboratory Records (RC)

40-42. Laboratory Records Dept.

\section{EXTERNAL DISTRIBUTION}

43. Bruce G. Buchanan, Computer Science Department, University of Pittsburgh, 206 Mineral Industries Building, Pittsburgh, PA 15260

44. Allan Hirsch, Vice President, Environmental Sciences, and Director, Washington Operations, 5109 Leesburg Pike, Suite 414, Falls Church, VA 22041

45. Helen Ingram, Director, Udall Center for Studies in Public Policy, University of Arizona, 803/811 East First Street, Tucson, AZ 85719

46. Calvin MacCracken, President, Calmac Manufacturing Corporation, 101 West Sheffield Avenue, P. O. Box 710, Englewood, NJ 07631

47. Jacqueline B. Shrago, Director, Office of Technology Transfer, 405 Kirkland Hall, Vanderbilt University, Nashville, TN 37240

48. Martin Williams, Professor, Department of Economics, Northern Illinois University, DeKalb, IL 60115

49.-58. OSTI, U. S. Department of Energy, P. O. Box 62, Oak Ridge, Tennessee 37831

59. Office of Assistant Manager for Energy Research and Development, DOE/ORO, P. O. Box 2001 Oak Ridge, TN 37831-8600

60.-800. External Energy Efficiency and Renewables Section Distribution Mailing List and extra copies to E.M. Schorn, 4500N, H-19A 

